\title{
Alicja Długołęcka
}

University of Physical Education, Warsaw

\section{The interactive context of discovering the category of corporeality in a phenomenological approach}

Where do you set boundaries between the I and it - BODY? Maybe there are no boundaries and maybe there is some kind of wall that went up between the two of you, the wall that you cannot break through. It is important what you think of your body... Maybe these thoughts make you treat your body the way you do.

(„Gratitiude”, Długołęcka, Pieńko, 2018, p. 17)

This article is an attempt to apply the phenomenological approach in research in the field of corporal psychology and physiotherapy. The author, taking Husserl's assumption, said that "no theory that one could come up with can deceive us as to this principle of all principles: that every source presenting visibility is the source of the legitimacy of knowing that everything that presents to us in "intuition"(to put it in this way: in its bodily reality) it should simply be taken as what it presents, but also only within the limits in which it presents itself" (Husserl, 1975, p. 87).

Edmund Husserl excluded the possibility of conducting proper research into knowledge derived from such sciences as mathematics and natural sciences. According to him, the beginning of research is a clean, direct way of revealing things in consciousness. The starting point for radical and autonomous knowledge is to see and describe what is directly given. This "seeing" is a kind of self-presentation (Selbstgegebenheit) of the object itself and only 
it can be considered as the real source of the certainty we seek (Święcicka, 1993, p. 40). The methodology based on these premises had to fulfil the postulate of "theoretically uninvolved description". Its implementation requires fulfilment of three conditions: adopting an objective attitude, consisting of paying attention only to the subject being examined, freeing oneself from all knowledge base on scientific and philosophical theories, and getting rid of all elements derived from tradition (Judycki, p. 5). Adopting these assumptions is particularly difficult in the area of the examination of the category of one's own corporeality.

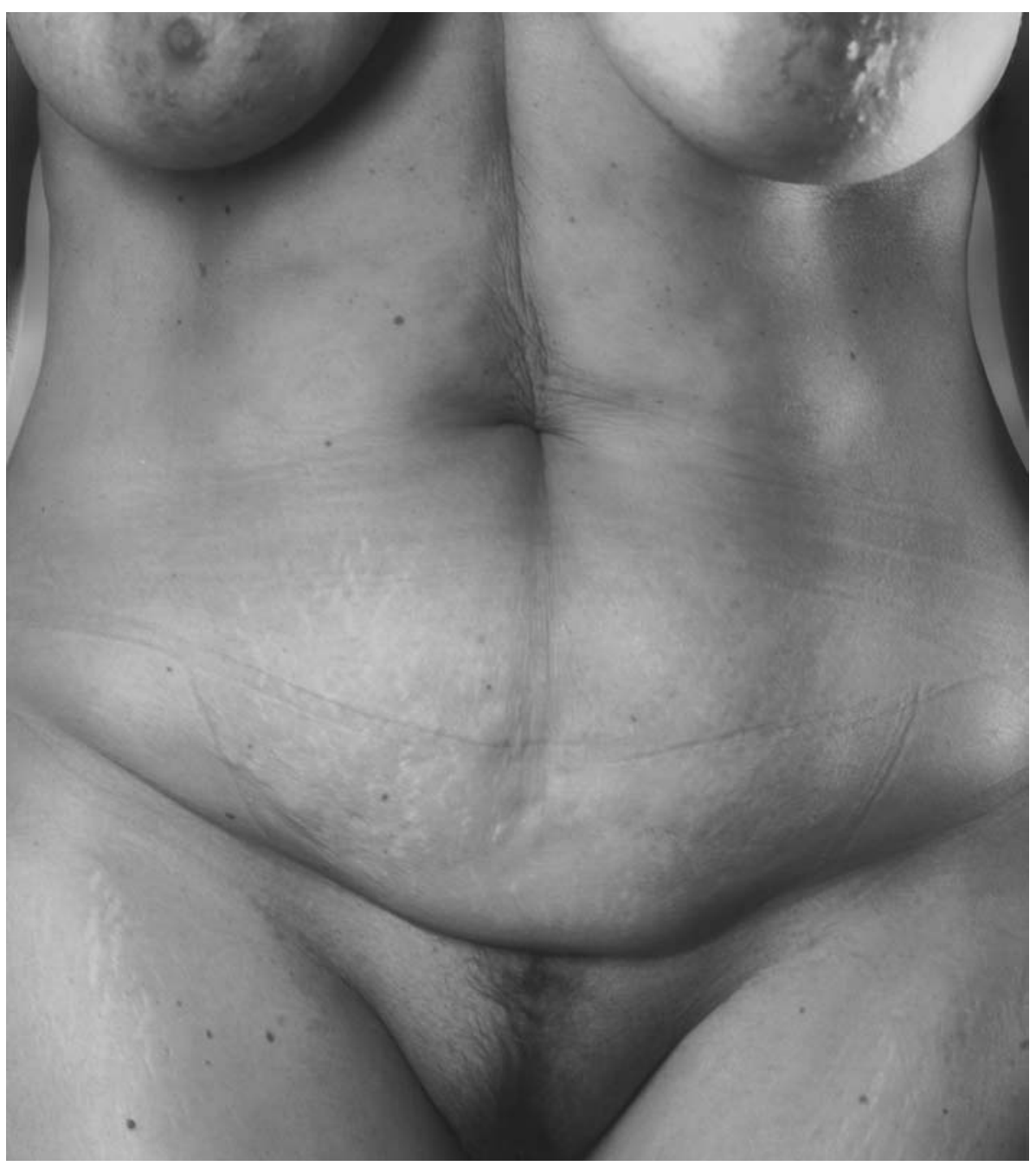

Fig. 1. 
Your own body is what a human never parts with from the beginning of one's existence until death. The act of learning about it becomes something unique because unlike other objects, your own body can be captured only from one perspective (Murawska, 2008). Despite social consciousness these days, where the Cartesian dualism of body and soul repents, Descartes himself had a sense of ambiguity about this separation. He wrote: "I am with the [body] as closely connected and as if mixed with it, so that I create with it a one whole" (Descartes, p. 96).

An illustration of the subjective concepts of the corporeality of the participants of the project are fragments of their statements (the authors publication):

The body is an instrument which is used mostly to practise sports, feeding a baby, moving around, going for a walk, carrying a baby...

The body is my clothing. Because there's something that is inside me, something that is the most important. But the body is also very important and it is unified with what I have inside. I always say that you should take care of your body. Because it's just like with a car. We take care of it, we want it to be clean, nice, and tidy. If it's scratched, we repair it as soon as possible, just after the incident. And we should treat the body in the same way. It is the only one we have for the whole life.

The body? Maybe it'll sound stupid but in a way it is a tool used to satisfy children' needs. I have the impression that it's like that ("Gratitiude", Długołęcka, Pieńko, 2018, pp. 18-19).

\section{Integrated concept of corporeality}

The ontological perspective of carnality in which the body becomes an integral part of the overall structure of oneself, owes its existence to philosophical and psychological directions only created in the second half of the twentieth century. Until then, in science in the area of Western culture, man was not one psychosomatic unity, but was the sum of the biological body - the subject of medical sciences and mind - the subject of psychology (understood, depending on the concept, as an area of consciousness-unconsciousness, self or ego). The first attempts of confrontation with ontological and epistemological problems of body and corporeality brought existential philosophy in relation to the ideas of: Martin Heidegger, Friedrich Nietzsche, Jean Paul Sartre, Sigmund Freud, Maurice Merleau-Ponty, and then Marc Johnson, George Lakoff, Patricia Churchland. It was Jean Sartre who drew attention to the fact that the concept of the body as an instrument of the subject is wrong, because in the 
case of the body and only the body, the roles of the subject and the object are inseparable - "the body is what is being watched and at the same time it is what is watching" (Sartre, 2007, p. 418). At the same time (Fritz Perls in 1969), psychology developed new branches described as Gestalt psychology and Gestalt therapy (Kepner, 1991).

I have always claimed - and I think it's still true - that the body is my tool, although I like more and more a quotation from Leśmian's poem: "I'm praying for a piece of immortality of your body" - and the poem is about a touch. So on the one hand, it is a tool but on the other, a piece of myself. It's difficult to express. When I grow old and start thinking what it will look like in time, I wonder what will be left of it. To what extent it is just matter and to what something more? More and more often it seems to me that it is something more.

The illness certainly changed a lot. My parents didn't tell me what condition I had. I found out after two months. I was a child and I didn't understand that I was mutilated (I had had my leg amputated). I thought only about what I wouldn't be able to do. Later I certainly started to treat it as something that I needed, this body of mine. Sometimes it says it needs me to take more care of it. Sometimes I need it to soothe myself, to cuddle up to myself, to be with myself. And sometimes this carnality and its limitations piss me off.

The most important thing is that my body, regardless of age, regardless of everything that happens to it, is still my body. Which means that it is one of the two most important things of mine - the other is my mind. We show some pieces of our body, use it. In such situations I feel I bare the other part of my being which is usually covered. ("Gratitiude", Długołęcka, Pieńko, 2018, pp. 19-20)

In the medical sciences there was a breakthrough as well - neurologist Antonio Damasio (2000) and neurophysiologists Lorie Humphrey, Peter Rosenfield (in: Mirucka, 2003) created the concepts of the constitutive body forming the basis of "I". Thanks to this new ontological perspective, the concept of "body image" began to function in the humanities at various levels: starting from the basic sensory phenomenon (body image) to the complex personality structure (body self) and it became possible to analyse the phenomenon of corporeality and "carnal me" (Mirucka, 2003).

Sociology (Marcel Mauss, Pierre Bourdieu, in: Wilkis, 2015) has introduced a new concept of understanding the body as a social tool, used depending on 


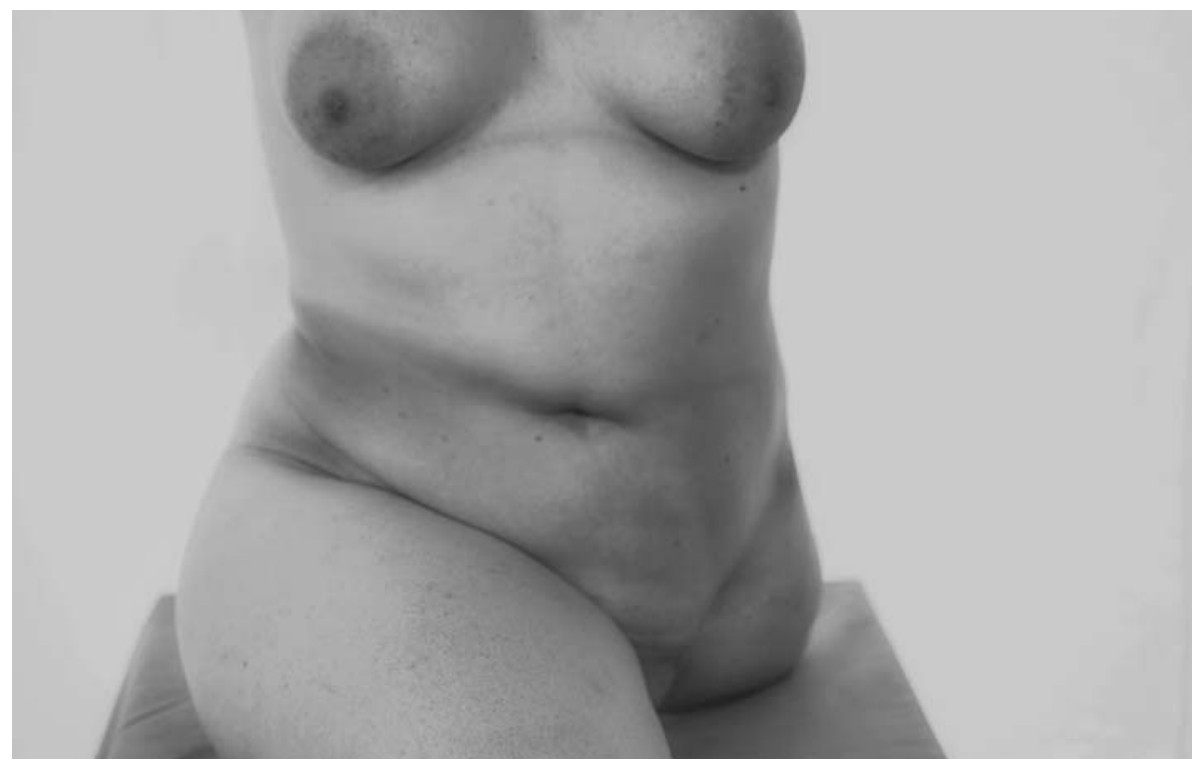

Fig. 2.

social position and prestige, gender, age, physical fitness and culture. Michel Foucault brought in a perspective in which he referred to the concept of power (Foucault, 2000) and was the first one to include the category of sexuality in discourse about the body particularly exposed to oppressiveness and control (biopolitics and biopower). According to him, the body was an object that could be transformed, changed and disciplined in specific social frameworks, and each element of the body (of a soldier, student, a patient, a woman or a man) corresponds to the pattern imposed by hierarchical power (Dominiak, 2007). Pierre Bourdieu also drew attention to the ways of social construction of physicality to the example of gender roles: male as dominant and active and feminine as submissive and passive. An important thesis that he put forward was that giving different meaning to corporeality results in experiencing it differently (Byczkowska, 2012). Judith Butler's analysis became a continuation of this thesis, which drew attention to the category of corporeality as a part of the construct of female identity. According to her (as cited in de Beauvoir) the body always has cultural meanings and just like the gender category is more of a "historical idea" than "a natural kind" (or "natural kind with historical essence”) (Bach, 2012, p. 231).

The body is something that makes it possible to contact other people on a level other than just bodily. It is great that thanks to my body I can meet other people, touch them, feel the touch, for example when I have a massage, when I cuddle up to somebody or just express any emotions... 
For me the body is a tool which allows me to be close to somebody. For me, my body is here and now. If I didn't have it, I wouldn't exist (“Gratitiude", Długołęcka, Pieńko, 2018, p. 19-20).

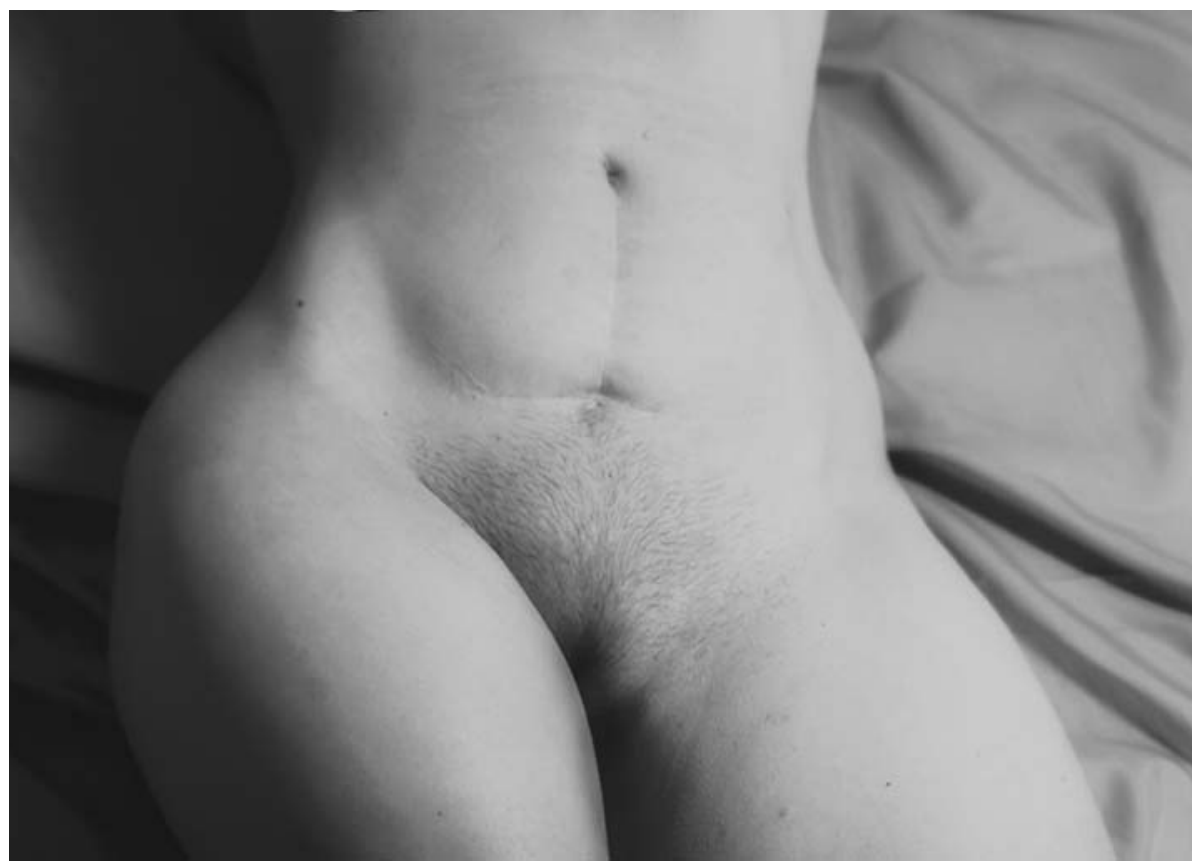

Fig. 3.

This creates a huge space for further consideration today in which, as Aleksandra Lemma writes: "The body in a different range and in different ways causes trouble for us all, sometimes it becomes the scene where conflict takes place and psychological pain is expressed (...). There is no doubt that the socio-cultural tension influences how we perceive and experience the body" (Lemma, 2014, p. 34).

Maurice Merleau-Ponty was the first to reject the Cartesian duality and he introduced the concept of Le chair as an important philosophical category -dimension of human existence (Murawska, 2008). He moved the emphasis of philosophical analyses of corporeality from social reality to experiencing one's own body in specific situations, tasks and contexts. According to MerleauPonty, the body has no sense beyond the context of the world, it is "our general way of possessing the world" (Merleau-Ponty, 2001, p. 166). The body in his view ceased to be an object, it became a phenomenon that we experience and 
transform and with which we communicate with others (Byczkowska, 2012). The subject for Merleau-Ponty becomes carnal. Le chair is a living, subjective corporeality (the subject is Le corps medical body). Merleau-Ponty writes about the status of his body: "Regardless of whether it is the body of another or my own, the only way of getting to know the human body is experiencing it, i.e. taking over the drama that penetrates it and uniting with it" (Merleau-Ponty, 2001, p. 256, for Murawska, 2008). The body in a phenomenological way becomes the most mysterious part of our identity and returns to the basic question of philosophy - questions about being of being (Heidegger, 2000, p. 144). It is because of a phenomenological thought about the body that the terms "corporeality" and "embodiment" are introduced by Thomas Csordas (Csordas, 2009). Corporeality becomes the embodiment of ideologies, social practices, states and traits. Anton Marczyński asking basic questions about being of a body and being the body introduces the category of the presence of the embodied, writing "The body never exists alone. Its essence is manifested and is only present thanks to the horizontality, context, all additions and admixtures" (Marczyński, 2016, p. 36). This way of thinking is consistent with the way of thinking about corporeality in psychology, e.g. in the concept of William James. He distinguishes two forms of experiencing Me: cognising Me (the I) and cognisable $\mathrm{Me}$ (the Me). As you can see this division is close to considering the bodily self in a subjective and objective manner. The subjective aspect of the carnal self is about experiencing oneself: perception, touching, thinking, feeling, experiencing, receiving sensations from the body, etc. The objective aspect is a collection of specific bodily experiences forming the bodily identity - a sense of durability, continuity and the uniqueness of your own corporeality (Mirucka, 2003). The epistemological area of the analysis of the phenomenon of the body and corporeality transferred from the ground of philosophy to the ground of psychology and broadened the range of interests from the area of "seeing" the body to the area of "feeling" it. The concept of the psychophysical unity of the subject, the subject being its body, the assembly of the cogniser with the object being studied, i.e. itself (Chirpaz, 1998), it enabled the definition of a theoretical construct on the basis of psychology, which is carnal me. According to this, carnal Me is: "the way of experiencing oneself in one's body with one's sexuality and a set of specific bodily experiences - conscious and unconscious - that are reflected in the image of one's body, which every subject possesses" (Mirucka, 2003, p. 223).

The body's self-identification set new areas of research and led to the integration of the concept of corporeality with medical sciences. Modern neurological research confirms the perspective of the physical (nervous) basis of 
consciousness, where the base is our whole body through the formation and development of carnal Me: "The representation of the organism in its own brain is probably the biological precursor of what ultimately becomes this ephemeral sense of Me" (Damasio, 2000, p. 31). Until the physical body is formed, the child is unable to differentiate between self and non-self, i.e. there is no boundary between the child and the mother. The first human consciousness that emerges is the body's consciousness, which is shaped by the mother's empathic presence (Mirucka, 2003). The experience of carnal Me in early phases of development is phased in and begins to be represented in the form of a body image and is the beginning of the individual's autonomy. According to Beata Mirucka, "In conclusion, carnal Me appears as the first subsystem of the self, I, allowing the individual to experience their physical separateness, coherence and identity" (Mirucka, 2003, p. 211). Continuation of this way of thinking about corporeality was provided by analyses of the gender category in the experience of corporeality. Research in the field of gender and queer, allowed to see the significance of the influence of cultural norms, the kind of upbringing and the influence of dominant discourses regarding the appearance of the body and giving meaning to its particular parts for shaping gender identity and different ways of using the body (Byczkowska, 2012). Sexual maturation and sexual relations are socially defined situations in which the corporeality of a woman and a man are intensively experienced and made present.

According to Gestalt therapy and subsequent therapies (e.g. Emotion Focused Therapy EFT, Focusing) the process of the body is the experience of Me. One can assume the hypothesis that people have embodied minds, and their conceptual systems are created by a living body, are shaped by it and thanks to it have meaning (Lakoff, 2003). Each psychological problem has its physical expression (pattern of muscle tension, breathing, small and large motor skills, etc.), and every somatic problem is a partial expression of psychic functions (Kepner, 1991).

The body is everything. I perceive the world with my body. I am my body. I don't really believe in life after life. It is me.

Generally, in my situation one needs to understand it: this is the only body I have (tears).

Now my body is me. Nothing is more me than what is here. Maybe there is a soul but it is not more me than my body and there is no qualitative difference between my immortal consciousness and my DNA, you see? And blood. (“Gratitiude”, Długołęcka, Pieńko, 2018, pp. 20-21)

The bodily self is most intensively registered in the Me system in excep- 


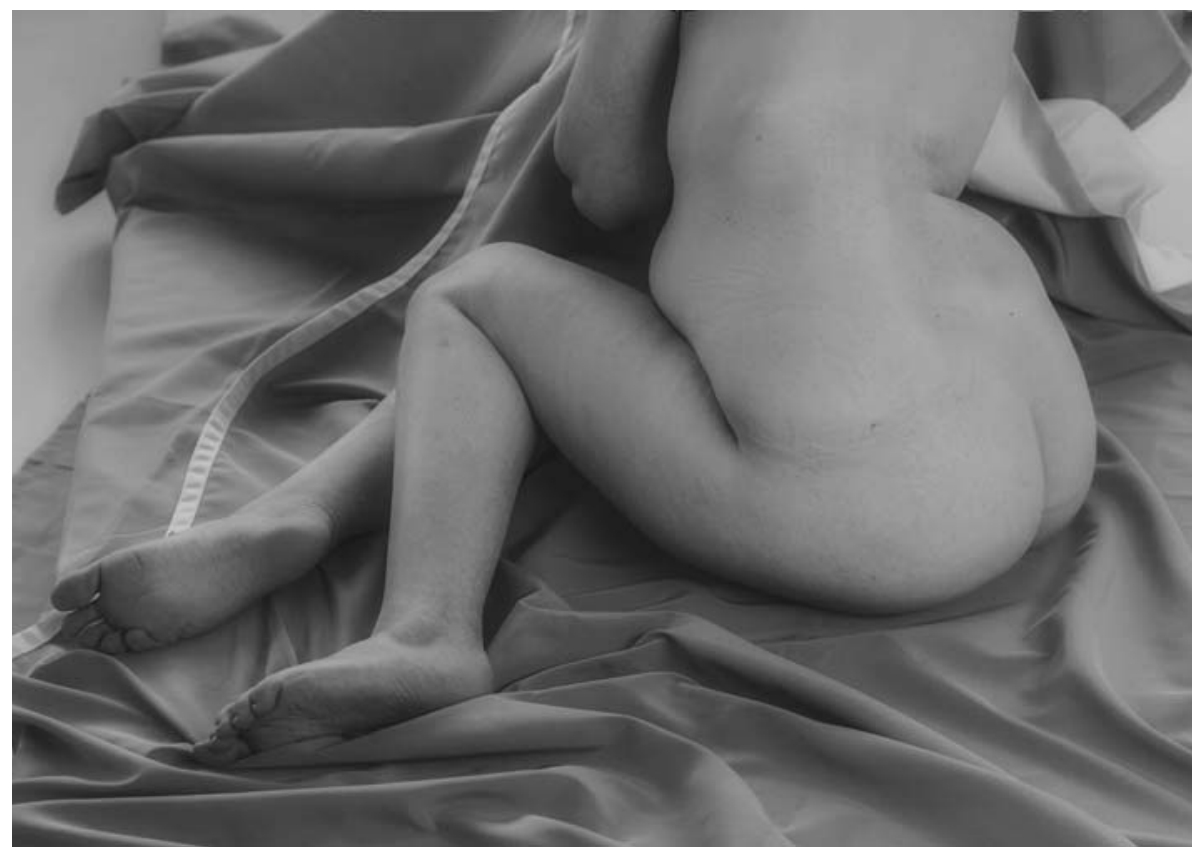

Fig. 4.

tional situations, not only in experiencing pain, fatigue, loss of fitness but also pleasure and desire (Chirpaz, 1998, Kepner, 1991). Me also allows oneself to experience itself as an integrated whole -self-acceptance as a bodily being and acceptance of my body. Sometimes due to the negation and rejection of corporeality, there is a permanent separation of the carnal Me from the Me system, taking the form of an inharmonious or broken personality structure (Mirucka, 2003). Aleksandra Lemma sums it up this way: "There is no doubt that sociocultural tensions affect how we perceive and experience the body. A bit more difficult truth to accept is that regardless of external pressures, it is difficult for us to integrate the body with the subjective self-experience, because it is the most emphatic proof of our ultimate dependence and helplessness: we are unable to either create ourselves or live forever "(Lemma, 2014, p. 34).

\section{The study of corporeality}

Dominika Byczkowska (2012) notices that in studying corporeality, particular methods are helpful where corporeality is not only studied from a distance because it cannot be "treated only as a narrative". The phenomenological approach is characterised by the observation of what appears, happens, without 
ontological anchoring. Marzena Adamiak writes that in the case of reference to one's own corporeality, the clarity of the phenomenological description is particularly difficult, "phenomenology was forced to set aside both the utopia of improperness and the dream of mathematical accuracy. There is still a metaphysical longing for discovering the essence of things and getting to the source of experience" (Adamiak, 2012).

The use of the method known as the "grounding theory" (first used by Barney Glaser and Anselm Strauss, 1967) seemed a reasonable solution in the research work. It is a qualitative research method that assumes, first and foremost, a lack of initial hypotheses and theory development through the systematic collection and analysis of data. The researcher must, therefore, be prepared to discover phenomena previously unpredictable and unplanned, which is referred to as the "interactive context of discovery" (Khan, 2014). The main goal of the grounded theory is to build the theory while conducting research, not to set up a priori hypothesis and to start empirical research after a thorough study of literature on the subject (Charmaz, 2009, p. 12).

The respondents of both qualitative studies came out of various concepts of carnality and "carnal me'-they represented all approaches. In the medical project, people as patients were much more likely to separate themselves from the "carnal me". Interestingly, in an arts-based research project in which female participants had the opportunity to experience corporeality in terms of security and mindfulness, the phenomenological description of carnality that inscribed the body into the structure of "Me" appeared much more often and became an inseparable element of self-awareness.

In the first qualitative studies, three groups of patients were analysed using this method ( 15 people in each group): patients over 60 years of age, patients with typical complaints of the musculoskeletal system aged 25-60, and patients with a physical disability.

In the first group, interestingly, the category of subordination to the therapist, cancellation of their own emotions emerging during the therapy, and giving meaning to the categories of care and mindfulness of the physiotherapist to the patients were clearly visible. Older patients during their in-depth free interview revealed their limits and expectations, often unconsciously. They focused on ethical categories (in the context of carnality) such as caring and mindfulness. 


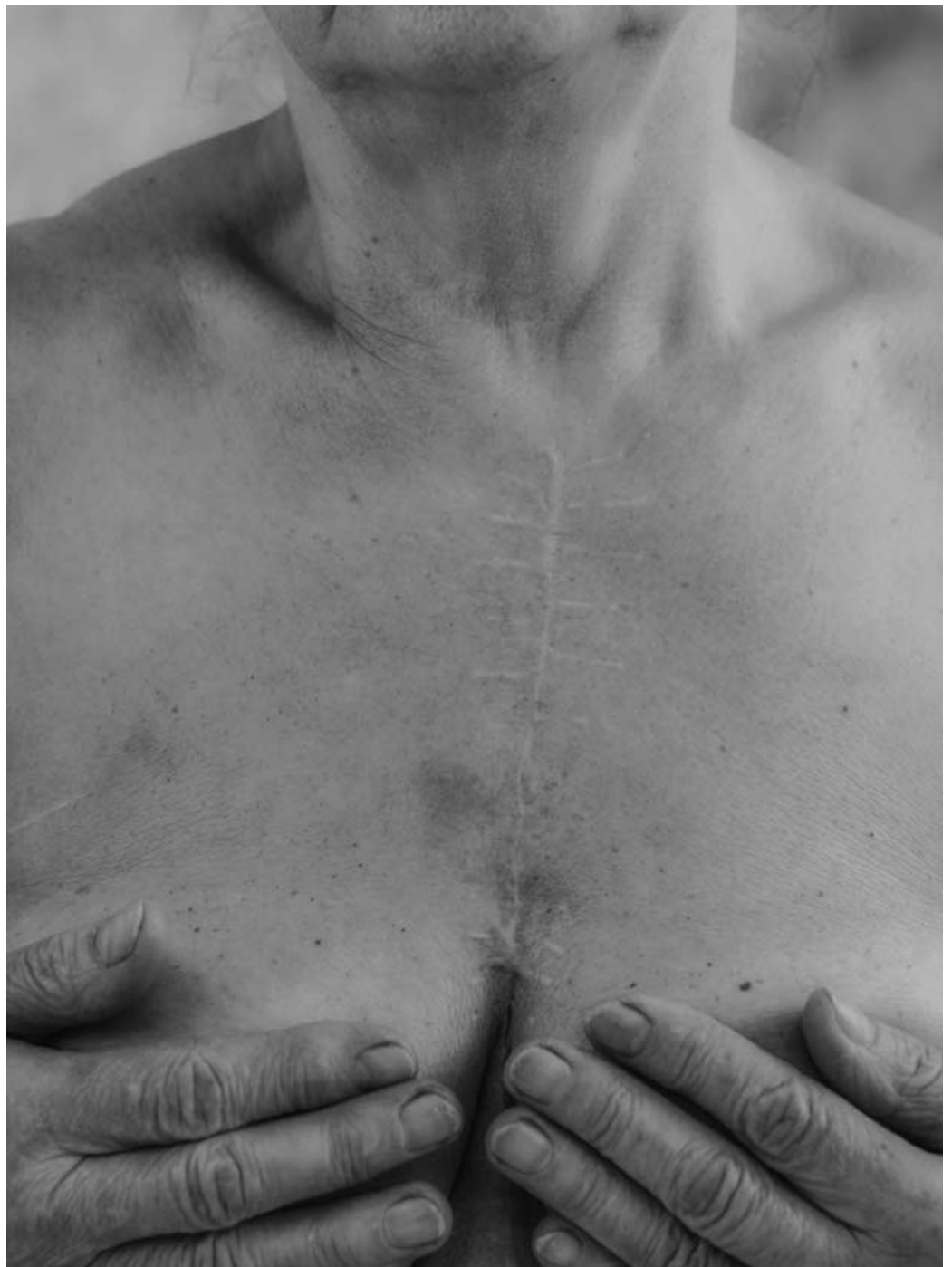

Fig. 5.

In the group of younger patients with typical musculoskeletal problems, the value of the recovery efficiency during therapy and the integrity of the therapist was the strongest. Patients in this group registered their emotions more than older ones while working on the body with a therapist: anxiety, embarrassment, a sense of security, trust or its violation. 
The group of patients with physical disabilities took a completely different perspective. Here, the phenomenon of "freezing feelings" and separation from the body as a result of the instrumental treatment of their corporeality clearly emerged. Often in the narrative there were such categories as: a sense of humiliation, neglect, depersonalisation. The value of autonomy/deciding about their bodily self in the therapy process was paramount in this group.

Femininity in all three groups, as a category coupled with corporeality, revealed phenomena related to violation of intimacy, feelings of shame, humiliation, assessment of appearance and unwanted, sexual contexts of therapeutic relationships.

The final analysis of the collected material revealed the basic psychological category associated with corporeality, touch and intimacy discovered in the therapeutic relationship - it was the deprivation of important needs. This is what generated expectations towards physiotherapists, awareness of certain aspects of carnality (and, consequently, their awareness) and ethical norms, which gave meaning to them.

The second study and, at the same time, the artistic project was a combination of the experimental method with the grounded theory method. It included an intimate photo session and a free interview deepened after the session. All the women who took part in the project had various motives. Some of them treated the session and interviews as a challenge, an attempt to stand up to their relationship to carnality, others as a crowning achievement of some important personal stage of their life, while others as participation in a sisterly undertaking.

They presented carnality in various dimensions: in youth and in maturity (the participants' age ranged from 18 to 75 ), figures and physiques. Two of them were pregnant, one has given birth recently. The group also included a transsexual woman, a woman who had had a leg amputated, a woman who had had a mastectomy, a woman with muscle atrophy resulting from a spinal cord injury, a woman who had had a stroke, a woman who had had a heart operation and a woman with Asperger syndrome.

The analysis of the report on how women experience one's corporeality clearly showed that the cultural context of the body has the strongest influence on the perception of the abdomen and vagina.

From the process of attentively experiencing corporeality during the session, the following stages have been distinguished:

giving meaning (SENSE),

analysis of body experiences in the course of life (MARKS),

\section{6}




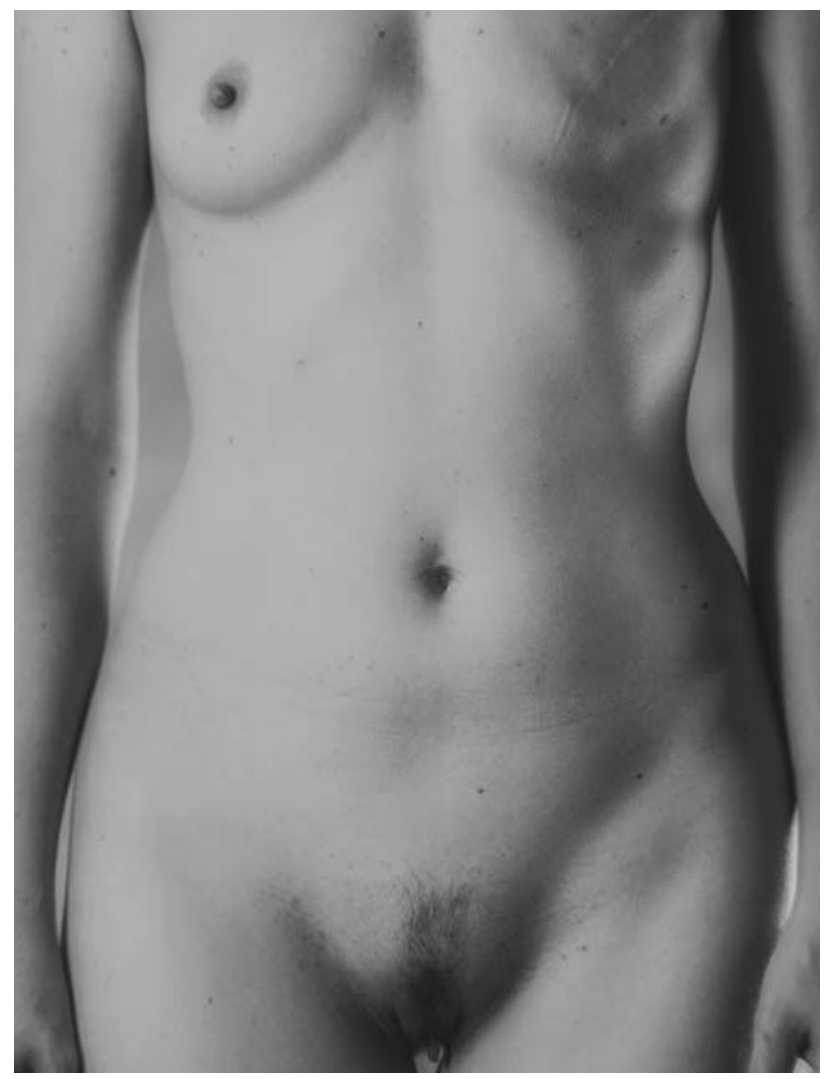

Fig. 6.

body evaluation (primarily negative aspects) (SHAPE) and, ultimately, openness and gratitude (OPENING UP and GRATITUDE) towards one's corporeality (hence the title of the project that emerged as a result of the analysis of statements using the grounded theory method).

The conditions conducive to contact with corporeality were time, mindfulness, lack of assessment and a sense of security.

\section{Conclusions}

The interactive context of discovering the category of corporeality in qualitative research makes it possible to discover and identify areas that are genuinely inscribed in it and whose analysis finds a legitimate justification. The outline of the research presented in this article indicates that the factors that influence the deepening of self-reflection regarding corporeality and the integration of the carnal Me with Me are borderline situations revealing our existence in a way that 
escapes objectivity, understood as a description of events in the subject's world (Kolasa, 2010). In the interactive context, such experiences as: maternal experience, body injuries, life-threatening diseases, physical exercise, ageing, positive sexual experiences in the period of maturity, nudity in contact with nature, but also severe deprivation of the need for autonomy, maintenance of borders concerning intimacy and mindfulness for corporeality in medical relations were most clearly revealed.

These are areas that remain open to phenomenological exploration in the subject of corporeality, both in research and theoretical dimensions.

\begin{abstract}
:
The article presents different ways of dealing with the subject of the body and corporeality in the humanities, which can form the epistemiological and axiological basis in a reflection on the psycho- and physiotherapeutic relationship with patients, and confronts them with the results of two qualitative studies based on the grounded theory concerning exploration by women of their own body and experiencing their own corporeality, intimacy and touch in medical relations ${ }^{1}$. The author shows that phenomenological philosophy, taking into account the concepts of "carnal self" and "presence of the embodied" that human knowledge always has a carnal character, is the most adequate for use in analyses regarding therapeutic interactions related to the body. Analysis of qualitative research on the process of realising your own corporeality in the cognitive-emotional dimension in the relationship with oneself and in the therapeutic relationship fully confirms the legitimacy of applying the grounded theory method in the study of phenomena regarding carnality and such values as gratitude, mindfulness, care, efficiency and autonomy emerge.
\end{abstract}

Keywords: body, corporeality, carnal self, embodied presence, care, gratitude, mindfulness, ethics of touch, therapeutic relation in physiotherapy

\title{
References:
}

Adamiak, M. (2012), Feminizm a fenomenologia - w kontekście poszukiwania albo konstruowania kobiecej tożsamości, Etyka, nr 45, pp. 62-72, http://bazhum.muzhp. $\mathrm{pl} / \mathrm{media} / /$ files/Etyka/Etyka-r2012-t45/Etyka-r2012-t45-s62-72/Etyka-r2012-t45s62-72.pdf, (accessed: 10.05.2019).

This paper is the result of research project no. 2016/21/B/HS1/01824 entitled 'A Physiotherapist's Ethics. Touch, Corporeality, Intimacy', which was funded by the National Science Centre. 
Bach, T. (2012), Gender Is a Natural Kind with a Historical Essence, Ethics, vol. 122, no.2, The University of Chicago Press.

Byczkowska, D. (2012), Cielesność, [w:] K. T. Konecki, P. Chomczyński, Stownik socjologii jakościowej, Warszawa: Difin SA, pp. 45-49.

Chirpaz, F. (1998), Ciato, (trans. J. Migasiński). Warszawa: IFiS PAN.

Charmaz, K. (2017). Teoria ugruntowana. Praktyczny przewodnik po analizie jakościowej, Warszawa: Wydawnictwo Naukowe PWN.

Thomas J. Csordas, T.J. (2009), The Somatic Modes of Attention, Cultural Anthropology vol. 8 , no. 2 .

Descartes, R. (2001), Medytacje o pierwszej filozofii. Zarzuty uczonych mężów i zarzuty autora. Rozmowa z Burmanem, (trans. M. i K. Ajdukiewiczowie, S. Swieżawski, I. Dąmbska), Kęty: Wydawnictwo Antyk.

Damasio, A. R. (2000), Tajemnica świadomości. Jak ciato i emocje wspóttworza świadomość, Poznań: Rebis.

Długołęcka, A., Pieńko, T. (2018), Wdzięczność, Warszawa/Lublin: Fundacja She/ Akapit.

Dominiak, Ł. (2007), Problematyka seksualności w filozofii politycznej Michela Foucaulta. Dialogi polityczne, nr 8. https://apcz.umk.pl/czasopisma index.php/DP/ article/viewFile/6513/5887, (accessed: 20.06.2019).

Foucault, M. (2000), Seksualność i wtadza, [w:] tenże, Filozofia, historia, polityka. Wybór pism (tłum. D. Leszczyński). Warszawa-Wrocław: Wydawnictwo Naukowe PWN.

Heidegger, M. (2000), Co zwie się myśleniem? (trans. J. Mizera). Warszawa: PWN.

Husserl, E. (1975), Idee czystej fenomenologii i fenomenologicznej filozofii. Księga pierwsza, ( przeł. D. Gierulanka). Warszawa: PWN.

Judycki, S. Fenomenologia jako filozofia kategorialna i transcendentalna. https://www. academia.edu/22259881/Filozofia_i_fenomenologia, (accessed: 20.11.2019).

Kepner, J. I. (1991), Ciato w procesie psychoterapii, Warszawa: Wydawnictwo Pusty Obłok.

Khan, S. (2014), Qualitative Research Method: Grounded theory, International Journal of Business and Management; Vol. 9, No. 11. https://www.researchgate.net/publication/287400872_Qualitative_Research_Method_Grounded_Theory, (accessed: 21.06.2019) Qualitative Research Method: Grounded Theory.

Kolasa, D. (2010), Sytuacje możliwe a sytuacje graniczne w filozofii Jaspersa, Studia z historii filozofii, nr 1. https://apcz.umk.pl/czasopisma/index.php/szhf/article/view/ szhf.2010.009/114, (accessed: 22.06.2019).

Lakoff, G. (2003), How the Body Shapes Thought: Thinking with an All Too Human Brain. [ In:] A. Sanford \& P. Johnson-Laird (Eds.), The Nature and Limits of Human Understanding, Edinburgh: T \& T Lark Publishers, Ltd.

Lemma, A. (2014), Pod skórą. Psychoanalityczne studium modyfikacji ciata, Gdańsk: Imago. 
Marczyński, A. (2016), Ciato/Mistyka. Wstęp do ontologii cielesności, Kraków: Wydawnictwo Benedyktynów.

Merleau-Ponty, M. (2001), Fenomenologia percepcji, (trans. M. Kowalska, J. Migasiński). Warszawa: Fundacja „Aletheia”.

Mirucka, B. (2003), Poszukiwanie znaczenia cielesności i ja cielesnego, Przegląd psychologiczny, vol. 46, no. 2.

Murawska, M. (2008), Tajemnica żywej cielesności: fenomenologia ciata w ujęciu Maurice'a Merleau-Ponty'ego i Michela Henry'ego, Sztuka i Filozofia , vol. 33.

Sartre, J.P. (2007), Byt i nicość. Zarys ontologii fenom enologicznej, (trans. J. Kiełbasa, P Mróz, R. Abramciów, R. Ryziński, P Matochleb,). Kraków: Zielona Sowa.

Święcicka, K. (1993), Husserl, Warszawa: Wiedza Powszechna.

Wilkis, A. (2015), Thinking the Body. Durkheim, Mauss, Bourdieu: The Agreements and Disagreements of a Tradition, https://www.researchgate.net/publication/301801202_ Thinking_the_Body_Durkheim_Mauss_and_Bourdieu, (accessed: 18.06.2019).

The Author of all presented photos is Tamara Pieńko. She is a photographer, artist and portraitist. She is the founder of the $S$ he foundation. In 2002 she obtained a Master degree in Economy. After a few years break she began postgraduate studies at the Institute of Creative Photography in Cracow. In 2006 she graduated with a Bachelor's degree for an artist-photographer. She takes portraits of film and theatre celebrities. She's fascinated by the world of music, and she's also been creating series of portraits of international artists for years.

She's the author of photography projects of a social nature. Her work exposes original topics referring to existentialism in its real human element. Over the last years, she's created original projects such as a unique series of photograms titled "Kolekcjonerzy" (the Collectors). The series presents passionate people whose existence often comes unnoticed to us. Another project titled "Eko rodzina" (Eco family) is about a story of a young married couple living outside the city. A very personal project titled "Wdzięczność" (Gratitude) is a fruitful result of a collaboration with Alicja Długołęcka. It combines subtle images with fragments of conversations with women who participated in the project. It's an individual study of emotions inscribed in the body.

Tamara's work and projects appeared in the press and magazines such as Twój Styl, Wysokie Obcasy, Wysokie Obcasy Ekstra, Logo, Pani, Press, Gala, Kikimora. She's the author of photographs in books published by the Edipresse publishing company. Her activism is also appreciated in commercial spheres. She's been working with numerous advertising companies for years. She's the initiator of workshops aimed at spreading photography knowledge. Her work was presented in exhibitions in various places in Poland. For more visit website: https://fundacjashe.pl/ 